\title{
Line $\times$ Tester Analysis of Tropical High Land Maize (Zea mays L.) Inbred Lines Top Crossed with Three East African Maize Populations
}

\author{
Teshale Assefa ${ }^{1,2 *}$, Habtamu Zeleke ${ }^{3}$, Thumasi Afriye ${ }^{4}$, Paul Otyama1 \\ ${ }^{1}$ Department of Agronomy, Iowa State University, Ames, IA, USA \\ ${ }^{2}$ Melkassa Agricultural Research Center, Nazreth, Ethiopia \\ ${ }^{3}$ Department of Plant Science, Haramaya University, Haramaya, Ethiopia \\ ${ }^{4}$ International Maize and Wheat Improvement Center (CIMMYT), Global Maize Program, Addis Ababa, Ethiopia \\ Email: ^tmamo@iastate.edu
}

How to cite this paper: Assefa, T., Zeleke, H., Afriye, T. and Otyama, P. (2017) Line $\times$ Tester Analysis of Tropical High Land Maize (Zea mays L.) Inbred Lines Top Crossed with Three East African Maize Populations. American Journal of Plant Sciences, 8, 126-136.

http://dx.doi.org/10.4236/ajps.2017.82010

Received: November 28, 2016

Accepted: January 17, 2017

Published: January 20, 2017

Copyright $\odot 2017$ by authors and Scientific Research Publishing Inc. This work is licensed under the Creative Commons Attribution International License (CC BY 4.0).

http://creativecommons.org/licenses/by/4.0/

\begin{abstract}
Maize breeding efforts to generate high yielding and adaptive cultivars have recently been given emphasis by national maize breeding program. In Ethiopia, the maize production system is mainly dominated by subsistence farmers where their production is below average. The objectives of this study were to determine the combining ability between lines and testers, and to evaluate the performance of crosses (hybrids) and parents for grain yield and yield component traits. Twenty-seven inbred lines were generated by crossing nine female lines (L1-L9) and three male testers (T1-T3) using line $\times$ tester mating system at International Maize and Wheat Improvement Center (CIMMYT), East African high land maize improvement program. The inbred lines along with parents were evaluated in randomized complete block design with two replications at three locations (Ambo, Kulumsa and Haramaya). Significant differences were observed among genotypes for all ten traits considered. Eight crosses $(\mathrm{L} 1 \times \mathrm{T} 2, \mathrm{~L} 1 \times \mathrm{T} 3, \mathrm{~L} 3 \times \mathrm{T} 3, \mathrm{~L} 8 \times \mathrm{T} 1, \mathrm{~L} 4 \times \mathrm{T} 2, \mathrm{~L} 9 \times \mathrm{T} 1, \mathrm{~L} 2 \times \mathrm{T} 1$, and $\mathrm{L} 2 \times \mathrm{T} 2$ ) had higher yield performance compared to other crosses across environments. Significant mean square differences were found across locations for general combining ability (GCA) due to lines for all traits except for number of kernel rows per ear, whereas GCA due to testers were significant only for grain yield, ear length and 1000-seed weight. Significant mean square due to GCA $\times$ Loc (both for lines and testers) was found for days to maturity $\left(38.71^{\star}\right), 1000$-seed weight $\left(4582.36^{* *}\right)$ and grain yield $\left(2756777^{* *}\right)$, while significant SCA $\times$ Loc interaction was found for all traits except number of kernel rows per ear (1.07), ear length (0.79) and ear diameter (0.12), suggesting that the importance of additive and non-additive gene effects in controlling these characters.
\end{abstract}




\section{Keywords}

Maize, Line, Tester, Combing Ability, Crosses

\section{Introduction}

Maize (Zea mays L.) is a member of grass family gramineae, to which all the major cereals belong. It is a diploid with $2 n=20$. It is one of the important crops growing in all parts of Ethiopia with high production in western, southwest and southern regions of the country [1]. According to Central Statistics Authority of Ethiopia, the production area for maize is significantly expanded to the most productive agricultural lands in the mid and highland areas of the country where it has been a minor crop in the past. This puts maize in the first position in total production and yield per unit area, and second after Teff (Eragrostis tef) in acreage among cereals. Some of the reasons for its rapid expansion were diverse use, wide adaptability, its high response to improved production packages, high yield per unit area and relative easiness of its production [2]. Maize has been put under a wider range of uses compared to any other cereals. It is used as human food, as feed grain, as fodder crop, and for hundreds of industrial purposes, this is due to its broad global distribution, and low price relative to other cereals, diverse grain types and its wide range of biological and industrial properties [3].

There is a great potential for maize production in Ethiopia and thus, the area, yield and production have been increasing for the last 10 years. However, the national average yield is still far below the world average. Such low yield is attributed mainly due to the lack of improved varieties for different agro-ecological regions particularly for highland maize growing environments [4].

The breeding program has emphasized the development of open pollinated varieties (OPVs) believing them to be more suitable for small farm agriculture with low inputs, but this breeding strategy has not shown the expected progress in maize seed industry as OPVs provide low response to improved packages and little incentive to private sector participation. Thus, the country has been importing hybrid seed for large state farms for many years [5] [6].

Effective selection method for grain yield and other desirable traits require information on the magnitude of useful genetic variances present in the population in terms of combining ability and association of component traits [7]. The combining ability between inbred lines and the three-popular east African populations (Ec.573, Kitale synthetic II and Kuleni) is not well established. The lack of information on combining ability between lines and open pollinated varieties necessitated introduction, crossing and evaluation of bulk of maize materials, which requires a lot of time, labor and expenses [8]. A suitable means to achieve this goal is the use of line $\times$ tester analysis system, a method that provides information about general and specific combining ability of parents and at the same time helpful in estimating various types of gene action. 
Combining ability analysis is one of the powerful tools in identifying the better combiners, which may be hybridized to exploit heterosis and to select crosses for direct use or for further breeding, although genetic studies have been made in maize in Ethiopia, little effort has been made to gather such information for highland areas of the country and this information also enables to make logical crosses (only between heterotic groups) and reduces the expense required for crossing and evaluation. Hence, this work was initiated with the objective of determining the combining ability of lines.

\section{Materials and Methods}

\subsection{Site Description}

Field experiments were carried out in 2001 at three locations in the sub humid region of central Ethiopia at Ambo Agricultural Research Center (AARC) of the Ethiopian Institute of Agricultural Research, $\left(8^{\circ} 57^{\prime} \mathrm{N} \& 38^{\circ} 07^{\prime} \mathrm{E}\right.$ at an altitude of $2175 \mathrm{~m}$ above sea level), with average annual rainfall of $1018.19 \mathrm{~mm}$, maximum and minimum temperature of $27^{\circ} \mathrm{C}$ and $10^{\circ} \mathrm{C}$, respectively. The soil at this location was Vertisols consisting of $67 \%$ clay, $18 \%$ silt, $15 \%$ sand and $1.5 \%$ organic (http://www.eiar.gov.et/index.php/research-centers). The $2^{\text {nd }}$ experimental station was Kulumsa Agricultural Research Center (KARC) of the Ethiopian Institute of Agricultural Research $\left(8^{\circ} 2^{\prime} \mathrm{N} \& 39^{\circ} 10^{\prime} \mathrm{E}\right.$ at an elevation of 2200 meter above sea level) with average annual rainfall of $840 \mathrm{~mm}$, maximum and minimum temperature of $22^{\circ} \mathrm{C}$ and $10^{\circ} \mathrm{C}$. The soil at KARC was clay. The $3^{\text {rd }}$ experimental station was Haromaya University (HU) research station $\left(9^{\circ} 24^{\prime} \mathrm{N}\right.$ and $42^{\circ} 03^{\prime} \mathrm{E}$ at an altitude of $1980 \mathrm{~m}$ above sea level). The soil was classified as fluvisol. All the three locations were representing mid to high land maize growing environments.

\subsection{Plant Materials and Experimental Design}

A total of 39 genotypes including 27 crosses derived by crossing nine female lines (L1-L9) and three male testers (T1-T3) using line $\times$ tester mating system [9] were obtained from the International Maize and Wheat Improvement Center (CIMMYT), East African highland maize improvement program. The list of the inbred lines and testers used in this experiment are given in Table 1. These inbred lines and testers were selected for their better yield potential and physiological maturity for high land maize growing agro-ecologies of Ethiopia. The tester lines used in these experiments were originally developed by CIMMYT and have been widely used to study combining ability of newly developed inbred lines by national maize breeding programs in east and central Africa regions. Meanwhile these testers are also used to group inbred lines into different heterotic groups. The experiment was arranged in randomized complete block design (RCBD) with two replications. Each plot consisted of two rows of $5.1 \mathrm{~m}$ long with spacing of $75 \mathrm{~cm}$ between rows and $30 \mathrm{~cm}$ between plants. Data collected were days to anthesis, days to silking, days to maturity, plant height, ear height, number of kernel rows per ear, ear length, ear diameter, 1000 kernel 
Table 1. Identification of the male and female parents used in the crosses.

\begin{tabular}{|c|c|}
\hline Lines (Females) & Pedigree \\
\hline L1 & $\{(\mathrm{KIT} / \mathrm{SNSYN}((\mathrm{N} 3 / \mathrm{TUX})\} \mathrm{clF} 1-\# \#\{\mathrm{GLS}=1)-12-2$ ENT 58/KS2 \\
\hline $\mathrm{L} 2$ & $\{\mathrm{KIT} / \mathrm{SNSYN}\{\mathrm{N} 3 / \mathrm{TUX}\}\} \mathrm{c1F} 1-\# \#(\mathrm{GLS}=1.5)-10-4 \mathrm{ENT} 42 / \mathrm{KS}$ \\
\hline L3 & $\{$ KIT/SNSYN $\{$ N3/TUX $\}$ c1F1-\#\# (GLS = 2)-2-1 ENT77/KS2 E \\
\hline $\mathrm{L} 4$ & $\{\mathrm{ECU} / \mathrm{SNSYN}\{\mathrm{SC} / \mathrm{ETO}\}\} \mathrm{clF} 1-\# \#(\mathrm{GLS}=2)-3-1 \mathrm{ENT} 39$ \\
\hline L5 & $\{$ ECU/SNSYN $\{$ SC/ETC $\}$ c1F1-\#\# (GLS-2.5)-1-1 ENT83 \\
\hline L6 & $\{$ ECU/SNSYN $\{\mathrm{SC} / \mathrm{ETO}\}\} \mathrm{clF} 1-\# \#(\mathrm{GLS}=2.5)-7-2 \mathrm{ENT} 91$ \\
\hline L7 & \{POOL 9Ac7-SR(BC2) FS123-1-2-2ENT 253 \\
\hline L8 & \{POOL 9 Ac7-SR(BC2) FS150-7-1-1ENT288 \\
\hline L9 & $\{$ POOL 9 Ac7-SR(BC2) FS111-6-2-3 ENT447 \\
\hline \multicolumn{2}{|l|}{ Testers (males) } \\
\hline $\mathrm{T} 1$ & Kitale syn 2 \\
\hline $\mathrm{T} 2$ & Ecuador 573 \\
\hline $\mathrm{T} 3$ & Kuleni \\
\hline
\end{tabular}

$\mathrm{L} 1-\mathrm{L} 9=$ Designation of lines and $\mathrm{T} 1-\mathrm{T} 3$ = Designation of Testers and hereafter these designations will be used throughout the text.

weight and grain yield. All the crop management and protection practices were applied based on the recommendation of each location.

\subsection{Data Analyses and Statistical Model}

All data collected for yield and yield related component traits were analyzed using Agrobase software version2. In the analyses, environments were considered as random and genotypes as fixed effects. Each of the three environments was first analyzed separately and then subjected to combined analysis. The combined analysis of variance over the three locations was done after testing the homogeneity of error variances using variance ratio. Similarly, analysis of variances was performed for combining ability using 27 crosses and cross plus parents, respectively, for individual and combined data.

General combining ability (GCA) and specific combining ability (SCA) were computed for characters that showed significant differences among crosses following Line $\times$ Tester analysis [9] using Agrobase and SAS computer programs. The statistical model used was as follows:

$$
Y_{i j k}=M+g_{i}+g_{j}+S_{i j}+r k+e_{i j k}
$$

where: $Y_{i j k}$ is any character measured on cross $i \times j$ in $k^{\text {th }}$ replication; $g_{i}=$ GCA effect of $i^{\text {th }}$ parent; $g_{j}=$ GCA effect of the parent $j ; S_{i j}=$ SCA effect of cross $i \times j$; $r k=$ replication effect; $e_{i j k}=$ environmental effect peculiar to $(i j k)^{\text {th }}$ individual, and $M=$ population mean effect.

\section{Results and Discussion}

Error mean square at the three locations (AARC, KARC and HU) showed ho- 
mogeneity for most of the traits, however, in some cases moderate heterogeneity for some of the traits was observed. According to Sokal and Rolf [10], the consequence of such cases is not expected to be too serious so we presented here the combined data analyses.

Significant differences were observed among the genotypes for days to tasseling, days to silking, days to maturity, plant height, ear height, ear length, ear diameter, number of kernel rows per ear, 1000-seed weight and grain yield except number of kernel per ear under combined analyses (Table 2). Similarly, significant $G \times E$ interaction was observed for days to anthesis, days to silking, days to maturity, ear height, plant height and 1000-seed weight were observed. This suggests that the genotypes tested in this study were different from each other for these traits. Therefore, phenotypic selection is feasible to identify the best crosses.

\subsection{Mean Performance}

The mean grain yield across environments was better for crosses such as $\mathrm{L} 1 \times \mathrm{T} 2$ $(11,360 \mathrm{~kg} / \mathrm{ha}), \mathrm{L} 1 \times \mathrm{T} 3(10,505 \mathrm{~kg} / \mathrm{ha}), \mathrm{L} 3 \times \mathrm{T} 3(10,469 \mathrm{~kg} / \mathrm{ha}), \mathrm{L} 8 \times \mathrm{T} 1(10,239$ $\mathrm{kg} / \mathrm{ha}), \mathrm{L} 4 \times \mathrm{T} 2(10,239 \mathrm{~kg} / \mathrm{ha}), \mathrm{L} 9 \times \mathrm{T} 1(10,139 \mathrm{~kg} / \mathrm{ha}), \mathrm{L} 2 \times \mathrm{T} 1(10,101 \mathrm{~kg} / \mathrm{ha})$, and L2 $\times$ T2 $(10,008 \mathrm{~kg} / \mathrm{ha})$, respectively (Table 3$)$. This suggests that these genotypes could be used as a potential source of genes for improving grain yield since they have more stable characters over environments. The highest 1000 seed weight was obtained from L6 $\times$ T3 $(508.1 \mathrm{gm})$ and L9 $\times$ T3 $(501.1 \mathrm{gm})$. The highest number of kernels per rows and number of rows per ear were recorded for L6 $\times$ T2 (41.8) and L9 $\times$ T1 (14.6), respectively, and the widest ear diameter was recorded for L $8 \times \mathrm{T} 1$, L9 $\times$ T1, and L6 $\times$ T3. The number of crosses showed better mean performance in yield components as compared to other hybrids could be used as source of genes for improving grain yield as well as indirect selection for grain yield per se.

\subsection{Analyses of Variance for Combing Ability}

Line $\times$ Tester Analysis was performed for all traits considered in this study fol-

Table 2. Analyses of variance for yield and yield related traits for crosses and their parents across locations.

\begin{tabular}{|c|c|c|c|c|c|c|c|c|c|c|c|c|}
\hline S. V & $\mathrm{DF}$ & DA & DS & $\mathrm{DM}$ & EHT & $\mathrm{PH}$ & EL & $\mathrm{ED}$ & RPE & YLD & TSW & KPR \\
\hline Loc & 2 & $3468^{\star *}$ & $3063^{\star *}$ & $4046^{* *}$ & $4639^{* *}$ & $8767^{\star *}$ & $254^{\star *}$ & $7.4^{\star}$ & 18 & 933,291 & $8469^{* *}$ & 10.2 \\
\hline Genotype & 38 & $64.4^{\star *}$ & $66^{* *}$ & $94.5^{\star \star}$ & $2026^{* *}$ & $3910^{* *}$ & $26^{* *}$ & $0.8^{* *}$ & $4^{\star *}$ & $32,332,885^{\star *}$ & $2984^{* *}$ & 10.2 \\
\hline $\mathrm{G} \times \mathrm{E}$ & 76 & $35.2^{\star *}$ & $33.8^{\star *}$ & $35.6^{* *}$ & $383^{* *}$ & $570^{* *}$ & 2.6 & 0.15 & 1.1 & 317,308 & $5007^{\star *}$ & 10.3 \\
\hline Error & 114 & 11.6 & 14.1 & 20.6 & 114 & 236 & 1.7 & 0.18 & 1.0 & 762,510 & 548.7 & 9.5 \\
\hline $\mathrm{CV}$ & & 3.6 & 3.8 & 2.4 & 10.0 & 7.6 & 7.5 & 9.2 & 8.1 & 11.0 & 5.9 & 8.5 \\
\hline
\end{tabular}

${ }^{\star *}$, ${ }^{\star}$ Significant at 1 and $5 \%$ level of probability, respectively. $S . V=$ Source variation, Loc $=$ Location, $\mathrm{G} \times \mathrm{E}$ $=$ Genotype $\times$ environment, $\mathrm{CV}=$ coefficient of variation. $\mathrm{DF}=$ degree of freedom, $\mathrm{DA}=$ days to anthesis, $\mathrm{DS}=$ days to silking, $\mathrm{DM}$ = days to maturity, $\mathrm{EHT}=$ ear height, $\mathrm{PH}=$ plant height, $\mathrm{EL}=$ ear length, $\mathrm{ED}=$ ear diameter, RPE = number of kernel rows, YLD = grain yield, TSW = 1000-seed weight, KPR = number of kernel per row. 
Table 3. Mean values of crosses and their parents for grain yield and components across environments.

\begin{tabular}{|c|c|c|c|c|c|c|c|c|c|c|c|}
\hline Crosses & Yield (kg/ha) & RPE & KPR & EL & $\mathrm{ED}$ & TSW & $\mathrm{DA}$ & DS & DM & EHT & $\mathrm{PH}$ \\
\hline $\mathrm{L} 1 \times \mathrm{T} 1$ & 9211 & 12.3 & 35.8 & 16.5 & 4.6 & 434.6 & 91 & 94 & 183.6 & 127.8 & 210.5 \\
\hline $\mathrm{L} 2 \times \mathrm{T} 1$ & 10,101 & 12.6 & 41.6 & 18 & 5 & 378.6 & 96.5 & 99 & 188.3 & 122 & 218.6 \\
\hline $\mathrm{L} 3 \times \mathrm{T} 1$ & 8628 & 12.3 & 37.6 & 17.8 & 4.6 & 338.8 & 93.8 & 96.3 & 190.3 & 124.1 & 229.3 \\
\hline $\mathrm{L} 4 \times \mathrm{T} 1$ & 9394 & 11.6 & 38.5 & 18.3 & 4.5 & 364 & 95 & 98.3 & 187 & 109.6 & 196.3 \\
\hline $\mathrm{L} 5 \times \mathrm{T} 1$ & 8320 & 12.3 & 40.3 & 17.8 & 4.3 & 415.6 & 95.6 & 101.1 & 195.5 & 114 & 210.1 \\
\hline $\mathrm{L} 6 \times \mathrm{T} 1$ & 9954 & 13 & 37.6 & 17.5 & 5 & 465.8 & 90.6 & 96.5 & 185.5 & 122 & 216.1 \\
\hline $\mathrm{L} 7 \times \mathrm{T} 1$ & 8808 & 13 & 35.3 & 17.5 & 5 & 413.5 & 92.5 & 95.1 & 185.5 & 110.1 & 197.3 \\
\hline $\mathrm{L} 8 \times \mathrm{T} 1$ & 10,239 & 13.6 & 38.1 & 18 & 5.1 & 492.6 & 97.3 & 100.6 & 187.1 & 125.3 & 220.5 \\
\hline $\mathrm{L} 9 \times \mathrm{T} 1$ & 10,139 & 14.6 & 39.1 & 18.1 & 5.1 & 470.3 & 92.5 & 95.3 & 188 & 129.8 & 227.6 \\
\hline $\mathrm{L} 1 \times \mathrm{T} 2$ & 11,360 & 13.6 & 39.8 & 20.8 & 4.6 & 448 & 94 & 97.8 & 186.5 & 131 & 225.8 \\
\hline $\mathrm{L} 2 \times \mathrm{T} 2$ & 10,008 & 13.6 & 38.6 & 19.1 & 5 & 461.5 & 95.5 & 98.1 & 186.3 & 110 & 203.5 \\
\hline $\mathrm{L} 3 \times \mathrm{T} 2$ & 9102 & 12 & 38.6 & 18.6 & 4.5 & 309.6 & 94.3 & 98.5 & 185.3 & 116.5 & 226.6 \\
\hline $\mathrm{L} 4 \times \mathrm{T} 2$ & 10,236 & 13 & 40.6 & 19 & 4.6 & 360.1 & 96.6 & 100 & 187 & 99.8 & 198.8 \\
\hline $\mathrm{L} 5 \times \mathrm{T} 2$ & 7759 & 13.3 & 39.6 & 18.5 & 4.6 & 395.3 & 97.8 & 104.1 & 192 & 110.5 & 207.1 \\
\hline $\mathrm{L} 6 \times \mathrm{T} 2$ & 9130 & 12.6 & 41.8 & 19.5 & 4.8 & 424 & 87.5 & 93.1 & 187.5 & 122.3 & 225.1 \\
\hline $\mathrm{L} 7 \times \mathrm{T} 2$ & 9387 & 13.6 & 36.3 & 17 & 4.8 & 474.1 & 89.1 & 92.6 & 188 & 103.8 & 192.1 \\
\hline $\mathrm{L} 8 \times \mathrm{T} 2$ & 8266 & 12 & 37 & 18 & 4.6 & 473.1 & 95.1 & 97.6 & 188.5 & 112.6 & 208.1 \\
\hline $\mathrm{L} 9 \times \mathrm{T} 2$ & 9563 & 13 & 36.6 & 17.3 & 4.8 & 473.5 & 91.5 & 95.3 & 187.5 & 112.8 & 235.6 \\
\hline $\mathrm{L} 1 \times \mathrm{T} 3$ & 10,505 & 12 & 37.6 & 18.5 & 4.8 & 458.3 & 92.3 & 97.8 & 181.5 & 118.1 & 218.5 \\
\hline $\mathrm{L} 2 \times \mathrm{T} 3$ & 7814 & 12.3 & 37 & 19.1 & 4.8 & 429.1 & 91.1 & 94.5 & 188.3 & 107.3 & 216.8 \\
\hline $\mathrm{L} 3 \times \mathrm{T} 3$ & 10,469 & 12 & 36 & 18.8 & 5 & 414.6 & 96 & 99.3 & 187.3 & 116.5 & 218.1 \\
\hline $\mathrm{L} 4 \times \mathrm{T} 3$ & 8641 & 13.6 & 39.3 & 18.5 & 4.6 & 376.5 & 90.8 & 94.6 & 177.6 & 109.6 & 216.5 \\
\hline $\mathrm{L} 5 \times \mathrm{T} 3$ & 8257 & 13 & 36.8 & 17.3 & 4.6 & 481 & 94.1 & 97.1 & 194.5 & 107 & 209.8 \\
\hline $\mathrm{L} 6 \times \mathrm{T} 3$ & 8161 & 12.6 & 40.6 & 18.8 & 5.1 & 508.1 & 90.6 & 96.1 & 183.3 & 114.5 & 221.3 \\
\hline $\mathrm{L} 7 \times \mathrm{T} 3$ & 5599 & 12.6 & 37.1 & 18.5 & 4.6 & 416.5 & 95.1 & 97.8 & 191.6 & 105.3 & 192.8 \\
\hline $\mathrm{L} 8 \times \mathrm{T} 3$ & 8370 & 13 & 39.8 & 20.1 & 5 & 443.8 & 95.3 & 99.5 & 190.8 & 120.6 & 222.3 \\
\hline $\mathrm{L} 9 \times \mathrm{T} 3$ & 8632 & 12.6 & 38.6 & 17.6 & 4.5 & 501.1 & 89.1 & 91.8 & 187.3 & 111.5 & 218 \\
\hline \multicolumn{12}{|l|}{ Parent } \\
\hline $\mathrm{T} 1$ & 8317 & 12.3 & 33.8 & 17.3 & 5 & 361.5 & 95.5 & 99.8 & 187.6 & 113.3 & 208.6 \\
\hline $\mathrm{T} 2$ & 8717 & 13 & 38.6 & 18.1 & 4.6 & 297.3 & 93.5 & 95.6 & 180.8 & 109.3 & 214.8 \\
\hline $\mathrm{T} 3$ & 8649 & 12.6 & 36.1 & 18.6 & 5 & 424.6 & 89.3 & 93.5 & 190.8 & 115.8 & 209.3 \\
\hline L1 & 4430 & 11.3 & 29 & 15 & 3.8 & 281.1 & 97.8 & 102.8 & 187.8 & 78.6 & 167.3 \\
\hline $\mathrm{L} 2$ & 4506 & 12 & 29.3 & 13.6 & 4 & 286.8 & 98 & 102.1 & 179.3 & 74 & 142 \\
\hline L3 & 3982 & 11.6 & 29.1 & 14.5 & 4.1 & 333.6 & 94.3 & 99.6 & 183.1 & 78.8 & 274.1 \\
\hline $\mathrm{L} 4$ & 3288 & 10.6 & 30.3 & 13.8 & 3.8 & 238.8 & 98.8 & 103 & 184.5 & 75.5 & 159.1 \\
\hline L5 & 4531 & 11.3 & 26.3 & 11.3 & 3.8 & 304.5 & 105 & 107.8 & 185.1 & 75.3 & 158.8 \\
\hline L6 & 4426 & 11 & 29.1 & 14.3 & 4.3 & 347 & 94.1 & 99.5 & 284.8 & 83.1 & 176.3 \\
\hline L7 & 4110 & 14 & 30.1 & 14 & 4.5 & 322.8 & 95.5 & 98.1 & 179.1 & 71.6 & 144 \\
\hline L8 & 4259 & 13.3 & 28.6 & 15 & 4.6 & 363.8 & 94.3 & 97.6 & 182.1 & 79.3 & 264.8 \\
\hline L9 & 3779 & 11.6 & 26 & 13.5 & 4.1 & 318.5 & 95.1 & 99.3 & 181.6 & 64 & 154.6 \\
\hline LSD (0.05) & 1729 & 2.03 & 6.1 & 2.6 & 0.8 & 46.4 & 6.7 & 7.4 & 8.9 & 21.1 & 30.4 \\
\hline
\end{tabular}

$\mathrm{DA}=$ days to anthesis, $\mathrm{DS}=$ days to silking, $\mathrm{DM}=$ days to maturity, $\mathrm{EHT}=$ ear height, $\mathrm{PH}=$ plant height, $\mathrm{EL}=$ ear length, $\mathrm{ED}=$ ear diameter, $\mathrm{RPE}=$ number of kernel rows, $\mathrm{YLD}=$ grain yield, $\mathrm{TSW}=1000$-seed weight, $\mathrm{KPR}=$ number of kernel per row. T1 = Tester-1, T2 $=$ Tester-2, T3 = Tester-3, L1 = Line-1, L2 = Line-2, L3 = Line-3, L4 = Line-4, L5 = Line-5, L6 = Line-6, L7 = Line-7, L8 = Line-8, L9 = Line-9. LSD = List significant difference. 
lowing the procedure described by Kempthorne [9]. Combined analysis of variance for GCA (general combining ability) showed that the mean square due to lines were significant for all the traits (Table 4), except for number of kernel rows per ear, whereas GCA mean squares due to tester were significant only for yield, ear length and 1000-seed weight. This suggested that additive gene effect was significantly important than non-additive gene effects for these traits. Meanwhile, the ratio of GCA/SCA mean square further supported the importance of additive gene actions in the inheritance of traits. The line $\times$ tester interaction (SCA) was significant for all traits considered, indicating that there were significant differences among crosses. Significant mean square due to GCA $\times$ Loc (both for lines and testers) was found for days to maturity $\left(38.71^{*}\right), 1000$ seed weight $\left(4582.36^{\star *}\right)$ and grain yield $\left(2756777^{\star *}\right)$, while significant SCA $\times$ Loc interaction was found for all traits except number of kernel rows per ear (1.07), ear length (0.79) and ear diameter (0.12), suggesting that the importance of additive and non-additive gene effects in controlling these characters. Similar results reported by Beck et al. [11] for SCA in grain yield, days to silking and plant height. Vasal et al. [12] also found significant mean squares due to SCA for plant height and grain yield in tropical $\times$ sub tropical crosses of maize germplasm. In this study, additive gene actions were important for ear length, ear diameter, and grain yield, suggesting that additive gene action is important for selection of quantitatively inherited traits [13].

\subsection{General Combining Ability Effects}

Estimates of GCA effects for combined analyses were presented in Table 5. The GCA effects were not estimated for some of the characters as mean square due to GCA was not significant in analysis of variance for combining ability. Highest

Table 4. Combining ability analysis of variance for yield and other agronomic characters across locations.

\begin{tabular}{cccccccc}
\hline \multicolumn{7}{c}{ MEAN SQUARES } \\
\hline Traits & GCA(L) & GCA(T) & SCA & GCA Lxloc & GCA Txloc & SCA xloc & Errors78 \\
\hline Yield & $9,682,103^{* *}$ & $15,511,249^{* *}$ & $6,514,825^{* *}$ & $2,756,777^{* *}$ & $6,082,835^{* *}$ & $3,761,554^{* *}$ & 516,847 \\
RPE & 1.77 & 1.55 & $2.86^{* *}$ & 0.82 & 0.51 & 1.07 & 1.02 \\
EL & $3.61^{*}$ & $14.56^{* *}$ & $5.13^{* *}$ & 1.06 & 0.39 & 0.79 & 1.55 \\
ED & $0.43^{*}$ & 0.13 & $0.25^{*}$ & 0.16 & $0.31^{*}$ & 0.12 & 0.12 \\
TSW & $35,188.02^{* *}$ & $12,388.46^{* *}$ & $6504.72^{*}$ & $4582.36^{* *}$ & $4697.56^{* *}$ & $4156.5^{* *}$ & 346.93 \\
DA & $85.51^{* *}$ & 17.9 & $28.33^{* *}$ & 14.22 & 15.87 & $19.42^{* *}$ & 9.83 \\
DS & $79.65^{*}$ & 16.37 & $33.44^{* *}$ & 16.13 & 14.43 & $23.1^{* *}$ & 11.37 \\
DM & $169.17^{* *}$ & 12.85 & $46.21^{* *}$ & $38.71^{*}$ & $58.41^{*}$ & $32.03^{*}$ & 19.94 \\
PHT & $1989.9^{* *}$ & 21.74 & $335.39^{*}$ & $493.8^{* *}$ & 215.18 & $440.97^{* *}$ & 194.51 \\
\hline
\end{tabular}

${ }^{* *},{ }^{*}=$ Significant at $1 \%$ and $5 \%$ level, respectively. GCA $(\mathrm{L})=$ GCA due to lines, GCA $(\mathrm{T})=$ GCA due to testers, GCA Lxloc = GCA line by location, GCA Txloc $=$ GCA due to tester by location, RPE $=$ number of kernel rows, $\mathrm{EL}=$ ear length, $\mathrm{ED}=$ ear diameter, $\mathrm{TSW}=1000$-seed weight, $\mathrm{DA}=$ days to anthesis, $\mathrm{DS}=$ days to silking, $\mathrm{DM}=$ days to maturity, $\mathrm{PH}=$ plant height. 
Table 5. Estimates of general combining ability (GCA) for yield and agronomic characters across location.

\begin{tabular}{|c|c|c|c|c|c|c|c|c|}
\hline $\begin{array}{l}\text { GCA effects } \\
\text { due to lines }\end{array}$ & Yield & EL & $\mathrm{ED}$ & TSW & DA & DS & $\mathrm{DM}$ & $\mathrm{PH}$ \\
\hline L1 & $1245.9^{* *}$ & 0.2716 & -0.07 & $16.5^{* *}$ & -0.93 & -0.33 & $-3.62^{*}$ & 4.04 \\
\hline L2 & 194.524 & 0.43 & 0.14 & -7.35 & 1.06 & 0.00 & 0.25 & -1.22 \\
\hline L3 & 286.358 & 0.104 & -0.07 & $-76.2^{* *}$ & 1.284 & 0.888 & 0.2593 & 10.493 \\
\hline L4 & 310.691 & 0.271 & -0.18 & $-63.5^{\star *}$ & 0.839 & 0.444 & $-3.629^{\star}$ & -10.339 \\
\hline L5 & $-1000.8^{* *}$ & -0.450 & -0.24 & 0.203 & 2.506 & $3.6^{* *}$ & $6.37^{* *}$ & -5.172 \\
\hline L6 & -31.8086 & 0.271 & 0.20 & $35.5^{\star *}$ & $-3.8^{\star *}$ & -1.77 & -2.18 & 6.660 \\
\hline L7 & $-11.821^{* *}$ & -0.672 & 0.03 & 4.259 & -1.160 & -2.22 & 0.925 & $-20.1^{* *}$ \\
\hline L8 & -154.642 & 0.382 & 0.14 & $39.4^{* *}$ & $2.61^{\star}$ & $2.2^{*}$ & 1.370 & 2.771 \\
\hline L9 & 332.024 & -0.6173 & 0.03 & $51.2^{\star *}$ & -2.38 & $-3.0^{*}$ & 0.2593 & 12.887 \\
\hline SE line & 293.49 & 0.5082 & 0.14 & 7.604 & 1.279 & 1.376 & 1.823 & 5.693 \\
\hline $\begin{array}{c}\text { GCA effect } \\
\text { due to testers }\end{array}$ & Yield & EL & $\mathrm{ED}$ & & & & & \\
\hline $\mathrm{T} 1$ & 308.598 & $-0.598^{\star *}$ & $-11.16^{*}$ & & & & & \\
\hline $\mathrm{T} 2$ & 310.2654 & 0.3272 & -6.0741 & & & & & \\
\hline $\mathrm{T} 3$ & $-618.84^{\star *}$ & 0.271 & $17.24^{* *}$ & & & & & \\
\hline SE tester & 169.451 & 0.293 & 4.3902 & & & & & \\
\hline $\operatorname{SE}\left(g_{i}-g_{j}\right)$ tester & 239.6 & 0.4149 & 6.20 & & & & & \\
\hline
\end{tabular}

$* *, *=$ Significant at $1 \%$ and $5 \%$ level, respectively. SE $=$ Standard error. T1 $=$ Tester- $1, \mathrm{~T} 2=$ Tester $-2, \mathrm{~T} 3=$ Tester-3, L1 = Line-1, L2 = Line-2, L3 = Line-3, L4 = Line-4, L5 = Line-5, L6 = Line-6, L7 = Line-7, L8 = Line-8, L9 $=$ Line-9. $\mathrm{SE}=$ standard error.

significant and positive GCA effects for grain yield was recorded for L1 across locations, revealed that parent L1 was proved to be a good general combiner, hence L1 can be used as potential source of additive gene effects to improve grain yield and yield components. High and significantly negative GCA effects for yield were recorded for L5, L7 and T3, suggesting that these lines are poor combiners to improve grain yield. Similar results were reported by Vasal et al. [14]. L1, L6, L8, and L9 showed significantly positive GCA effects for 1000-seed weight, showing that they are good general combiners for this trait. Genotypes such as L1, L2, L3, L4, L6, L8, T2 and T3 showed positive estimates of GCA effects for the ear length, suggesting that these lines are good combiner to improve ear length in maize. L5 was good general combiner for both days to silking and maturity if lateness is considered, whereas L1 and L4 were good general combiners for maturity traits when earliness is considered.

\subsection{Estimation of Specific Combing Ability Effects}

Estimates of specific combining ability (SCA) effects for combined environments were presented in Table 6. It can be seen from the results that most of the combinations had statistically non-significant SCA effects for most of the traits. 
Table 6. Estimates of specific combining ability effects of line $\times$ tester crosses for yield and agronomic characters across locations.

\begin{tabular}{|c|c|c|c|c|c|c|c|c|c|}
\hline $\begin{array}{l}\text { SCA effects } \\
\text { due to } \\
\text { crosses }\end{array}$ & Yield & RPE & EL & ED & TSW & DA & DS & $\mathrm{DM}$ & $\mathrm{PH}$ \\
\hline $\mathrm{L} 1 \times \mathrm{T} 1$ & $-1455^{\star \star}$ & -0.29 & -1.51 & -0.09 & -1.166 & -2.209 & -2.40 & 0.585 & -7.623 \\
\hline $\mathrm{L} 2 \times \mathrm{T} 1$ & 484.912 & -0.185 & -0.18 & 0.018 & $-33.277^{\star}$ & 1.790 & 1.59 & 0.259 & 5.820 \\
\hline $\mathrm{L} 3 \times \mathrm{T} 1$ & $-1080.2^{\star}$ & 0.259 & 0.012 & -0.09 & -4.722 & -1.432 & -1.963 & 2.259 & 4.765 \\
\hline $\mathrm{L} 4 \times \mathrm{T} 1$ & -338.432 & -1.07 & 0.320 & 0.148 & 8.277 & 0.345 & 0.48148 & 2.814 & -7.401 \\
\hline $\mathrm{L} 5 \times \mathrm{T} 1$ & -100.543 & -0.52 & 0.543 & -0.26 & -3.833 & -0.654 & 0.25926 & 1.148 & 1.265 \\
\hline $\mathrm{L} 6 \times \mathrm{T} 1$ & 563.734 & 0.259 & -0.51 & -0.04 & 11.00 & 0.679 & 0.7037 & -0.296 & -4.567 \\
\hline $\mathrm{L} 7 \times \mathrm{T} 1$ & 568.123 & -0.07 & 0.432 & 0.129 & -10.05 & -0.320 & -0.2963 & -3.40 & 3.376 \\
\hline $\mathrm{L} 8 \times \mathrm{T} 1$ & 972.234 & 0.814 & -0.12 & 0.185 & $3.944^{*}$ & 0.901 & 1.037 & -2.185 & 3.654 \\
\hline $\mathrm{L} 9 \times \mathrm{T} 1$ & 386.067 & 0.814 & 1.043 & 0.296 & -0.166 & 0.901 & 0.592 & -0.074 & 0.709 \\
\hline $\mathrm{L} 1 \times \mathrm{T} 2$ & 691.012 & 0.814 & $1.89^{*}$ & 0.000 & 7.074 & 1.530 & 0.925 & 2.370 & 8.098 \\
\hline $\mathrm{L} 2 \times \mathrm{T} 2$ & 389.567 & 0.592 & 0.061 & 0.111 & $44.46^{* *}$ & 0.864 & 0.592 & -1.518 & -8.956 \\
\hline $\mathrm{L} 3 \times \mathrm{T} 2$ & -608.265 & -0.29 & -0.10 & -0.17 & $-38.48^{\star *}$ & -0.380 & 0.037 & -2.518 & 2.487 \\
\hline $\mathrm{L} 4 \times \mathrm{T} 2$ & 502.234 & 0.037 & 0.061 & -0.11 & -0.648 & 2.419 & 1.814 & 3.037 & -4.512 \\
\hline $\mathrm{L} 5 \times \mathrm{T} 2$ & -663.376 & 0.259 & 0.283 & 0.166 & $-29.25^{\star}$ & 1.753 & 2.925 & -2.296 & -1.345 \\
\hline $\mathrm{L} 6 \times \mathrm{T} 2$ & -261.765 & -0.29 & 0.561 & -0.11 & $-35.92^{\star}$ & -2.246 & -2.296 & 1.925 & 4.820 \\
\hline $\mathrm{L} 7 \times \mathrm{T} 2$ & $45.45^{\star}$ & 0.370 & -0.99 & 0.055 & $45.51^{\star *}$ & -3.246 & -2.962 & -0.518 & -1.401 \\
\hline $\mathrm{L} 8 \times \mathrm{T} 2$ & -1002.76 & -1.07 & -1.05 & -0.22 & 9.351 & -1.024 & -1.962 & -0.296 & -8.290 \\
\hline $\mathrm{L} 9 \times \mathrm{T} 2$ & -192.088 & -0.41 & -0.72 & 0.055 & -2.092 & 0.308 & 0.925 & -0.185 & 9.098 \\
\hline $\mathrm{L} 1 \times \mathrm{T} 3$ & 764.808 & -0.52 & -0.38 & $0.92^{*}$ & -5.91 & 0.679 & 1.481 & -1.851 & -0.475 \\
\hline $\mathrm{L} 2 \times \mathrm{T} 3$ & -874.469 & -0.41 & 0.117 & -0.13 & -11.18 & -2.654 & -2.185 & 1.259 & 3.135 \\
\hline $\mathrm{L} 3 \times \mathrm{T} 3$ & $1688.5^{\star *}$ & 0.037 & 0.12 & 0.259 & $43.20^{* *}$ & 1.790 & 1.925 & 0.259 & -7.253 \\
\hline $\mathrm{L} 4 \times \mathrm{T} 3$ & -163.802 & 1.037 & -0.38 & 0.037 & -0.629 & -2.765 & -2.296 & -5.851 & 11.915 \\
\hline $\mathrm{L} 5 \times \mathrm{T} 3$ & 763.919 & 0.259 & 0.827 & 0.092 & $33.092^{*}$ & -1.098 & -3.18 & 1.148 & 0.080 \\
\hline $\mathrm{L} 6 \times \mathrm{T} 3$ & -301.969 & 0.037 & -0.05 & 0.148 & 24.925 & 1.567 & 1.592 & -1.629 & -0.253 \\
\hline $\mathrm{L} 7 \times \mathrm{T} 3$ & $-1713^{\star *}$ & -0.29 & 0.561 & -0.19 & $-35.46^{*}$ & 3.567 & 3.259 & 3.925 & -1.975 \\
\hline $\mathrm{L} 8 \times \mathrm{T} 3$ & 30.53 & 0.259 & 1.172 & 0.037 & $-43.29^{\star *}$ & 0.123 & 0.925 & 2.481 & 4.635 \\
\hline $\mathrm{L} 9 \times \mathrm{T} 3$ & -193.96 & -0.41 & -0.33 & -0.35 & 2.259 & -1.209 & -1.519 & 0.259 & -9.808 \\
\hline SE SCA & 508.35 & 0.707 & 0.880 & 0.244 & 13.17 & 2.21 & 2.384 & 3.15 & 9.86 \\
\hline $\operatorname{SE}\left(S_{i j}-S_{j k}\right)$ & 718.92 & 1.00 & 1.245 & 0.346 & 18.62 & 3.13 & 3.77 & 4.465 & 13.94 \\
\hline
\end{tabular}

Crosses $\mathrm{L} 3 \times \mathrm{T} 3$ and $\mathrm{L} 7 \times \mathrm{T} 2$ were the only crosses that had significant and positive SCA effects for grain yield and 1000-seed weight, suggesting that these two crosses combined well to give higher grain yield and 1000-seed weight than the mean performance of their respective parents. On the other hand, L1 $\times \mathrm{T} 1, \mathrm{~L} 3 \times$ T1, and L7 $\times$ T3 were poor combiners with statistically negative significant SCA 
effects $\left(-1455^{* \star},-1080.2^{\star}\right.$ and $-1713^{* \star}$ respectively). In this study, manifestation of good SCA may not be expected since some of the parents involved to produce the $F_{1}$ hybrids are broad based populations. Several authors indicated that good GCA effect is obtained from broad based parents (full-sibs, half sibs, population and composites) while good SCA is exhibited by narrow based parents (inbred lines) upon crossing. Such differences are especially a matter of differences in gene frequency. In broad based parents, gene frequency is not easy to determine compared to narrow based parents gene frequencies [15]. L1 $\times \mathrm{T} 2$ and L1 $\times$ T3 showed positive and significant SCA effects for ear length and ear diameter, respectively, indicating that they are good specific combiners for the above-mentioned traits. $\mathrm{L} 8 \times \mathrm{T} 1, \mathrm{~L} 2 \times \mathrm{T} 2, \mathrm{~L} 7 \times \mathrm{T} 2, \mathrm{~L} 3 \times \mathrm{T} 3$, and $\mathrm{L} 5 \times \mathrm{T} 3$ crosses had significant and positive SCA effects, whereas $\mathrm{L} 2 \times \mathrm{T} 1$, $\mathrm{L} 3 \times \mathrm{T} 2$, $\mathrm{L} 5 \times \mathrm{T} 2$, L6 $\times$ T2, L7 $\times$ T3 and L8 $\times$ T3 produced significant and negative SCA effects for 1000-seed weight.

\section{Conclusion}

The analyses of variance for combining ability across locations indicated that mean squares due to lines were significant for all traits except number of kernel rows per ear, whereas mean squares due to testers were significant for yield, ear length and 1000-seed weight. The line $\times$ tester interaction was significant for all traits considered, suggesting that there were differences among F1 hybrids. The estimates of GCA effects in combined analyses revealed that L1 was good general combiner for grain yield and other related traits and had negative significant GCA effects for days to maturity. This line could possibly be used to develop high yielding with early maturing genotypes. Considering the performance of specific crosses as estimated by specific combining ability effects across locations, cross between good general combiners was not necessarily good specific combiners, so only L7 $\times$ T2 and L3 $\times$ T3 had good SCA effects for grain yield and 1000-seed weight. Generally, the results obtained in this study indicated that lines developed from Kitale Synthetic II combined well with Tester 2 (T2) and vice versa.

\section{Acknowledgements}

We are grateful to Ethiopian Agricultural Research Organization for providing funds to the research work. Some special thanks also goes to staffs at Ambo agricultural research center, Kulumsa agricultural research center and Haromaya University who supported us throughout this study.

\section{References}

[1] Getinet, G., Tesfaye, Z., Abebe, K. and Kiflu, B. (1995) The Institute of Agricultural Research. Its Role in the Development of Ethiopian Agriculture. In: Breth, S.A., Ed., Achieving Greater Impact from Research Investment in Africa, Sasakawa Africa Association, Mexico City.

[2] Tolosa, B. (1988) Genetic Improvement of Maize in Ethiopia. Strategies and 
Progress Made, 446-480.

[3] Watson, A. (1988) Corn Marketing, Processing and Utilization. In: Sprague, G.F. and Dudeley, J.W., Eds., Corn and Corn Improvement, 3rd Edition American Society of Agronomy, Madison, Wisconsin, 490-495.

[4] Mulatu, K., Bogale, G., Tolosa, B., Yigzaw, W. and Assefa, D. (1993) Maize Production Trends in Ethiopia. Progress Report, Ethiopian Institute of Agricultural Research (EIAR), Addis Ababa, Ethiopia.

[5] Tolessa, B., Mulatu, K., Wolde, L., Worku, M. and Tulu, L. (1996) Reflection of the Successful Achievements of Hybrid Maize Breeding Program in Ethiopia. Fifth Eastern and Southern Africa Regional Maize Conference, Arusha, 3-7 June 1996, 67-71.

[6] Tolosa, B., Kebede, M., Wolde, L., Bogale, G., Mosisa, W. and Keneni, G. (1997) Heterosis and Genetic Diversity in Crosses of adapted East African Maize Composites. In: Book of Abstracts. The Genetics and Exploration of Heterosis, 82-83.

[7] Hallauer, A.R. and Miranda, J.B. (1988) Quantitative Genetics in Maize Breeding. 2nd Edition, Iowa State University Press.

[8] Adera, G. (1991) Evaluation of Inbred Lines, Their Combining Ability in Diallel Crosses and Testing of Double Crosses of Maize (Zea mays L.). M.Sc. Thesis, Alemaya University of Agriculture, Ethiopia.

[9] Kempthorne, O. (1957) An Introduction to Genetic Statistics. John Wiley and Sons, Inc., New York.

[10] Sokal, R. and Rohl, F.J. (1969) Biometry. The Principles and Practices in Biological Research. W. H. Freeman and Co., New York.

[11] Beck, D.L., Vasal, S.K. and Crossa, J. (1990) Heterosis and Combining Ability of CIMMYT'S Tropical Early and Intermediate Maturity Maize (Zea mays L) Germplasm. CIMMYT. Maydica, 35, 279-285.

[12] Vasal, S., Srinivasan, G., Beck, D.L., Crosa, J., Pandey, S. and De Lean, C. (1992b) Heterosis and Combining Ability of CIMMYT'S Tropical Late White Maize Germplasm. Maydica, 37, 217-223.

[13] Moll, R.H. and Stuber, C.W. (1974) Quantitative Genetics Empirical Results Relevant to Plant Breeding. Advances in Agronomy, 26, 277-313. https://doi.org/10.1016/S0065-2113(08)60874-3

[14] Vasal, S.K., Dhillon, B.S., Srinivasan, G., Mc Clean, S.D., Zhang, S.H. and Gonzalez, F. (1994) Breeding Inter Synthetic Hybrids to Exploit Heterosis in Maize. Maydica, 39, 183-186.

[15] Falconer (1988) Introduction to Quantitative Genetics. Longman, New York. 
Submit or recommend next manuscript to SCIRP and we will provide best service for you:

Accepting pre-submission inquiries through Email, Facebook, LinkedIn, Twitter, etc. A wide selection of journals (inclusive of 9 subjects, more than 200 journals)

Providing 24-hour high-quality service

User-friendly online submission system

Fair and swift peer-review system

Efficient typesetting and proofreading procedure

Display of the result of downloads and visits, as well as the number of cited articles Maximum dissemination of your research work

Submit your manuscript at: http://papersubmission.scirp.org/

Or contact ajps@scirp.org 